\title{
DETERMINAN KEJADIAN OSTEOPOROSIS PADA PASIEN DI RSUP DR. WAHIDIN SUDIROHUSODO KOTA MAKASSAR
}

\section{DETERMINANT OF OSTEOPOROSIS OCCURRENCE ON PATIENTS IN REGIONAL GENERAL HOSPITAL, WAHIDIN SUDIROHUSODO IN MAKASSAR CITY}

\author{
Suryanti Tukiman ${ }^{1}$, Andi Zulkifli ${ }^{1}$, Ridwan Thaha ${ }^{2}$ \\ ${ }^{1}$ Bagian Epidemiologi, Fakultas Kesehatan Masyarakat, Universitas Hasanuddin \\ ${ }^{2}$ Bagian Promosi Kesehatan, Fakultas Kesehatan Masyarakat, Universitas Hasanuddin
}

*Alamat Korespondensi :Suryanti Tukiman, Fakultas Kesehatan Masyarakat Universitas Hasanuddin, J1. A.P.
Pettarani 3 No. 67 Makassar, santi.fkmuh@gmail.com, HP: 085340168485

\begin{abstract}
Abstrak
Osteoporosis merupakan penyakit yang ditandai dengan rendahnya massa tulang dan memburuknya mikrostruktural jaringan tulang. Penelitian ini bertujuan menganalisis faktor risiko osteoporosis pada pasien penderita osteoporosis di RSUP Dr. Wahidin Sudirohusodo.Penelitian ini merupakan jenis penelitian analitik dengan rancangan studi kasus kontrol.Populasi adalah semua penderita osteoporosis di RSUP Dr. Wahidin Sudirohusodo.Sampel sebanyak 122 orang yang terdiri atas 61 orang penderita osteoporosis sebagai kelompok kasus dan 61orang bukan penderita osteoporosis sebagai kelompok kontrol.Penarikan sampel dilakukan secara purposive sampling.Pengumpulan data dilakukan dengan menggunakan lembar observasi.Data dianalisis menggunakan analisis risiko (odds Ratio) dan Pearson Chi Square untuk analisis bivariat, serta regresi logistik untuk analisis multivariate. Hasil penelitian menunjukkan bahwa variabel yang berisiko terhadap osteoporosis adalah riwayat keluarga (OR:2,052; 95\%CI:1,70-2,46; p:0,079), aktivitas fisik (OR:6,71; 95\%CI:3,04-14,8; p:0,000), konsumsi makanan sumber kalsium (OR:5,497; 95\%CI:2,44-12,35; p:0,000), dan konsumsi minuman bersoda (OR:2,997; 95\%CI:1,194-7,520; p:0,016). Hasil analisis multivariat menunjukkan bahwa aktivitas fisik (OR:4,370; 95\%CI:1,856-10,288; p:0,001), konsumsi makanan sumber kalsium (OR:3,150; 95\%CI:1,283-7,736; p:0,012), dan konsumsi minuman bersoda (OR:2,371; 95\%CI:0,851-6,606; p:0,099) merupakan faktor risiko yang paling berkontribusi terhadap osteoporosis.
\end{abstract}

Kata Kunci: Faktor risiko, Osteoporosis, Densitas Massa Tulang (DMT)

\begin{abstract}
Osteoporosis is a disease characterized by low bone mass and worsening of microstructural bone tissue.The research aimed at analyzing the osteoporosis risk factors on the osteoporosis patients in the Regional General Hospital, Wahidin Sudirohusodo. This was the analytic research with the control case study design. The research population was all osteoporosis patients in the Regional General Hospital, Wahidin Sudirohusodo with as many as 122 samples comprising 61 osteoporosis patients as the case group and 61 non-osteoporosis patients as the control group. The samples were taken using the purposive sampling technique. Data were collected using the observation sheet. The data were analyzed using the risk analysis (Odds Ratio) and Pearson Chi-Square for the bivariate analysis, and logistic regression for the multivariate analysis. The research result indicates that the variables having the risk of the osteoporosis are: family history (OR:2,052; 95\%CI:1,70-2,46; p:0,079), physical activity (OR:6,71; 95\%CI:3,04-14,8; p:0,000), consumption of calcium source food (OR:5,497; 95\%CI:2,4412,35; p:0,000), and consumption of soft drink (OR:2,997; 95\%CI:1,194-7,520; p:0,016). The multivariate analysis result indicates that the physical activity (OR:4,370;95\%CI:1,856-10,288; p:0,001), consumption of calcium source food (OR:3,150; 95\%CI:1,283-7,736; p:0,012), and consumption of soft drink (OR:2,371; 95\% CI:0,851-6,606; p:0,099)represent the risk factors having the most significant contribution on the osteoporosis.
\end{abstract}

Keywords: Risk Factor, Osteoporosis, Bone Mass Density (BMD) 


\section{PENDAHULUAN}

Osteoporosis merupakan penyakit metabolik tulang yang mempunyai sifatsifat khas dan sering disbut sebagai 'silent disease'. Laporan International Osteoporosis Foundation mengemukakan bahwa osteoporosis mempengaruhi sekitar 200 juta wanita di seluruh dunia, dengan estimasi $1 / 10$ pada wanita usia 60 tahun; 1/5 pada wanita usia 70 tahun; 2/5 pada wanita usia 80 tahun; dan $2 / 3$ pada wanita usia 90 tahun (IOF, 2010b).Saat ini, sekitar 5,5 juta orang penduduk Eropa menderita patah tulang akibat osteoporosis (Hernlund et al., 2013).Di sini terlihat bahwa prevalensi osteoporosis di dunia cukup tinggi.

Di Indonesia, berdasarkan hasil analisa data risiko osteoporosis pada tahun 2005 dengan jumlah sampel 65.727 orang (22.799 laki-laki dan 42.928 perempuan) yang dilakukan oleh Puslitbang Gizi Depkes RI menunjukkan angka prevalensi osteopenia (osteoporosis dini) sebesar 41,7\% dan prevalensi osteoporosis sebesar 10,3\%. Ini berarti 2 dari 5 penduduk Indonesia memiliki risiko untuk terkena osteoporosis (Depkes, 2008). Hal ini juga didukung oleh data Indonesian White Paper yang dikeluarkan oleh Perhimpunan osteoporosis Indonesia (Perosi) pada tahun 2007 yaitu osteoporosis pada wanita yang berusia di atas 50 tahun mencapai 32,3\% dan pada pria usia diatas 50 tahun mencapai 28,85\%. Secara keseluruhan percepatan proses penyakit osteoporosis pada wanita sebesar $80 \%$ dan pria $20 \%$ (Trihapsari, 2009).

Di Sulawesi Selatan khususnya di Makassar, berdasarkan data dari Dinas Kesehatan Republik Indonesia Propinsi Sulawesi Selatan yang dilaporkan oleh Syahrir et al. (2015) didapatkan bahwa jumlah pasien rawat jalan yang menderita osteoporosis sebanyak 199 kasus. Laporan Rekam Medik di RSUP Dr.Wahidin Sudirohusodo tahun 2012-2015 diketahui jumlah penderita osteoporosis bersifat fluktuatif. Pada tahun 2012 tercatatat sebanyak 49 pasien dan pada tahun 2013 mengalami penurunan dengan jumlah pasien sebanyak 45, kemudian tahun 2014 kembali mengalami peningkatan dengan jumlah pasien 149 dan di tahun 2015 tercatat Januari-Mei, jumlah pasien osteoporosis sebanyak 44 pasien (RSUP, 2015).

Hal ini menunjukkan bahwa osteoporosis merupakan salah satu masalah kesehatan masyarakat yang membutuhkan perhatian serius.Selain karena prevalensinya yang terus meningkat, akibat yang ditimbulkan karena penyakit osteoporosis ini juga cukup berat. Menurut IOF (2010a), insiden fraktur osteoporosis per tahun pada wanita lebih tinggi dibandingkan angka insiden gabungan antara serangan jantung, stroke, dan kanker payudara. Sedangkan menurut World Health Organization (WHO) dalam (IOF (2010b)), osteoporosis merupakan penyakit kedua setelah penyakit kardiovaskular sebagai masalah global.

Akibat atau dampak lain yang ditimbulkan oleh penderita osteoporosis adalah risiko mengalami fraktur yang dapat meningkatkan beban sosio ekonomi berupa biaya perawatan yang besar. Selain itu juga menyebabkan kecacatan, ketergantungan pada orang lain yang menyebabkan gangguan aktivitas hidup, fungsi sosial, dan gangguan psikologis sehingga terjadi penurunan kualitas hidup bahkan sampai menyebabkan kematian. Risiko kematian bagi pria yang menderita osteoporosis sama dengan orang yang menderita kanker prostat. Sedangkan risiko kematian bagi wanita sama dengan orang yang menderita kanker payudara, bahkan lebih tinggi dari orang yang menderita kanker Rahim (Tandra, 2009).

Studi pendahuluan yang dilakukan oleh Juniati et al. (2012) di RS Islam Faisal tentang faktor-faktor yang berhubungan dengan osteoporosis menunjukkan bawha sebanyak $62,5 \%$ yang menderita osteoposis. Penelitian tersebut menggunakan desain cross sectional dengan sampel yang sangat sedikit yaitu 16 orang.Berdasarkan studi pendahuluan 
sebelumnya dan melihat prevalensi osteoporosis yang semakin meningkatseiring dengan meningkatnya usia harapan hidup serta dampak yang ditimbulkan akibat penyakit tersebut semakin serius, sehingga peneliti tertarik untuk melakukan penelitian tentang analisis determinan kejadian osteoporosis di RSUP Dr. Wahidin Sudirohusodo Makassar dengan mengembangkan desain penelitian yaitu case control dan memperbesar jumlah sampel dalam penelitian.Selain itu, alasan peneliti tertarik untuk mengkaji determinan kejadian osteoporosis karena data hasil peneltian tentang faktor risiko terjadinya osteoporosis khususnya di Makassar masih sangat terbatas.

\section{BAHAN DAN METODE}

\section{Lokasi dan Desain Penelitian}

Penelitian ini dilaksanakan di rumah sakit yaitu RSUP Dr. Wahidin Sudirohusodo.Jenis penelitian yang digunakan adalah observasional analitik dengan rancangan kasus kontrol yang bertujuan untuk mengkaji hubungan antara paparan (yakni jenis kelamin, riwayat keluarga, penyakit sistemik diabetes mellitus, aktivitas fisik, konsumsi makanan sumber kalsium, konsumsi kopi, konsumsi the, dan konsumsi soft drink) dankejadian osteoporosis dengan membandingkan antara kelompok kasus dan kelompok kontrol.

\section{Populasi dan Sampel}

Populasi dalam penelitian ini adalah semua pasien osteoporosis (laki-laki dan perempuan) yang tercatat dalam rekam medis RSUP Dr. Wahidin Sudirohusodo tahun 2012-2015.Besarsampel dalam penelitian ini sebanyak 122 orang yang terdiri atas 61 orang pasien osteoporosis (laki-laki dan perempuan) berumur $\geq 50$ tahun sebagai kelompok kasus dan 61orang tetangga dari pasien osteoporosis (laki-laki dan perempuan) berumur $\geq 50$ tahun sebagai kelompok kontrol yang dipilih secara purposive sampling dan telah memenuhi kriteria inklusi yaitu: pasien (laki-laki dan perempuan) berumur $\geq 50$ tahun baik rawat inap dan rawat jalan yang didiagnosis menderita osteoporosis, memiliki data rekam medis yang lengkap, dan bertempat tinggal di kota Makassar.

\section{Metode Pengumpulan Data}

Pengumpulan data dilakukan melalui penggunaan data sekunder berupa data rekam medis penderita osteoporosis di RSUP Dr. Wahidin Sudirohusodo tahun 2012-2015 dan data primer melalui wawancara terhadap responden.

\section{Analisis Data}

Data dianalisis secara bivariat untuk melihat distribusi karakteristik umum responden dan menguji hubungan setiap varibel independen terhadap variabel dependen menggunakan Odds Ratiodan Pearson Chi-Square. Analisis multivariat dilakukan untuk menguji hubungan secara langsung antar variabel menggunakan uji regresi logistik.

\section{HASIL PENELITIAN \\ Karakteristik Responden}

Jumlah responden yang tergolong dalam jenis kelamin perempuan merupakan jenis kelamin dengan proporsi kasus tertinggi yaitu sebesar 63,9\%.Berdasarkan kelompok umur, mayoritas responden dengan proporsi tertinggi terdapat pada kelompok umur 5559 tahun dan 60-64 tahun yaitu masingmasing sebesar $23 \%$. Berdasarkan tingkat pendidikan dan pekerjaan responden, sebesar $45,9 \%$ responden berpendidikan SD dan $47,5 \%$ responden yang bekerja sebagai ibu rumah tangga (Tabel 1).

\section{Analisis Bivariat}

Jumlah responden yang tergolong dalam jenis kelamin berisiko tinggi pada kelompok kasus sebesar 64\%, sedangkan pada kelompok kontrol sebesar 54\%.Berdasarkan hasil analisis risiko, nilai OR untuk jenis kelamin adalah 1,504 hal tersebut menunjukkan bahwa responden yang berjenis kelamin perempuan memiliki risiko 1,50 kali lebih besar untuk mengalami osteoporosis dibandingkan dengan responden yang berjenis kelamin laki-laki. Nilai 95\% confidence interval berdasarkan hasil analisis berada dalam 
rentang 0,728-3,108. Oleh karena nilai batas bawah dan batas atas 95\% CI mencakup nilai 1 maka jenis kelamin bukan merupakan faktor risiko yang signifikan terhadap kejadian osteoporosis (Tabel 2).

Tabel 1. Distribusi Karakteristik Umum Responden Di RSUP Dr.Wahidin Sudirohusodo Tahun 2012-2014

\begin{tabular}{lcccccc}
\hline Karakteristik & \multicolumn{2}{c}{ Kasus } & \multicolumn{2}{c}{ Kontrol } & \multirow{2}{*}{ Total } & \multirow{2}{*}{ \% } \\
$\quad$ Responden & $\mathbf{n}$ & $\mathbf{\%}$ & $\mathbf{n}$ & $\mathbf{\%}$ & & \\
\hline Jenis Kelamin & 22 & 36,1 & 28 & 45,9 & 50 & 41,0 \\
Laki-laki & 39 & 63,9 & 33 & 54,1 & 72 & 59,0 \\
Perempuan & & & & & & \\
Kelompok Umur & 6 & 9,8 & 27 & 44,3 & 33 & 27,0 \\
50-54 Tahun & 14 & 23,0 & 22 & 36,1 & 36 & 29,5 \\
55-59 Tahun & 14 & 23,0 & 8 & 13,1 & 22 & 18,0 \\
60-64 Tahun & 10 & 16,4 & 4 & 6,6 & 14 & 11,5 \\
65-69 Tahun & 9 & 14,8 & 0 & 0 & 9 & 7,4 \\
70-74 Tahun & 8 & 13,1 & 0 & 0 & 8 & 6,6 \\
75-79 Tahun & & & & & & \\
& & & & & & \\
Pendidikan & 3 & 4,9 & 0 & 0 & 3 & 2,5 \\
Tidak Sekolah & 28 & 45,9 & 3 & 4,9 & 21 & 25,4 \\
SD & 13 & 21,3 & 9 & 14,8 & 22 & 18 \\
SMP & 12 & 19,7 & 23 & 37,7 & 35 & 28,7 \\
SMA & 5 & 8,2 & 26 & 42,6 & 31 & 25,4 \\
Akademi/PT & & & & & & \\
Pekerjaan & & & & & & \\
IRT & 29 & 47,5 & 13 & 21,3 & 42 & 34,4 \\
Wiraswasta & 12 & 19,7 & 18 & 29,5 & 30 & 24,6 \\
Pegawai Swasta & 6 & 9,8 & 7 & 11,5 & 13 & 10,7 \\
PNS & 7 & 11,5 & 12 & 19,7 & 19 & 15,6 \\
Petani/nelayan & 6 & 9,8 & 11 & 18,0 & 17 & 13,9 \\
Lainnya & 1 & 1,6 & 0 & 0 & 1 & 0,8 \\
\hline
\end{tabular}

\section{Sumber: Data Primer, 2015}

Jumlah responden yang memiliki riwayat keluarga yang pernah menderita osteoporosis pada kelompok kasus sebesar 4.9\% sedangkan pada kelompok kontrol tidak ada.Berdasarkanhasil analisis risiko, nilai OR untuk riwayat keluarga adalah 2,05 yang menunjukkan bahwa responden dengan riwayat keluarga yang pernah mengalami osteoporosis memiliki risiko 2,05 kali untuk mengalami osteoporosis dibandingkan dengan keluarga yang tidak pernah mengalami osteoporosis. Nilai $95 \%$ confidence interval berdasarkan hasil analisis berada dalam rentang 1,70-2,46.
Oleh karena nilai batas bawah dan nilai batas atas $95 \%$ CI tidak mencakup nilai 1 maka riwayat keluarga merupakan faktor risiko yang signifikan terhadap kejadian osteoporosis (Tabel 2).

Jumlah responden yang memiliki riwayat diabetes mellitus pada kelompok kasus sebesar $31,1 \%$ sedangkan pada kelompok kontrol sebesar 19.7\%.Berdasarkan hasil analisis risiko, nilai OR untuk riwayat diabetes mellitus adalah 1,84 yang menunjukkan bahwa responden yang memiliki riwayat diabetes mellitus akan berisiko 1,84 kali lebih besar 
untuk mengalami osteoporosis dibandingkan dengan responden yang tidak memiliki riwayat diabetes mellitus. Nilai 95\% confidence interval berdasarkan hasil analisis berada dalam rentang 0,80-4,24. Oleh karena nilai batas bawah dan batas atas 95\% CI mencakup nilai 1 maka riwayat diabetes mellitus bukan merupakan faktor risiko yang signifikan terhadap kejadian osteoporosis (Tabel 2).

Jumlah responden yang tidak teratur berolaharaga pada kelompok kasus sebesar $70,5 \%$ sedangkan pada kelompok kontrol hanya sebesar 26,2\%.Berdasarkan hasil analisis risiko, nilai OR untuk aktivitas fisik adalah 6,71 yang menunjukkan bahwa responden yang tidak teratur dalam berolaharaga akan berisiko 6,71 kali lebih besar untuk mengalami osteoporosis dibandingkan dengan responden yang teratur dalam berolahraga. Nilai $95 \%$ confidence interval berdasarkan hasil analisis berada dalam rentang 3,04-14,84. Oleh karena nilai batas bawah dan batas atas $95 \%$ CI tidak mencakup nilai 1 maka aktivitas fisik merupakan faktor risiko yang signifikan terhadap kejadian osteoporosis (Tabel 2).

Jumlah responden yang kurang mengkonsumsi makanan sumber kalsium pada kelompok kasus sebesar 80,3\% sedangkan pada kelompok kontrol sebesar 42,6\%. Berdasarkan hasil analisis risiko, nilai OR untuk konsumsi makanan sumber kalsium adalah 5,49 yang menunjukkan bahwa responden yang kurang mengkonsumsi makanan sumber kalsium akan memiliki risiko 5,49 kali untuk mengalami osteoporosis dibandingkan dengan responden yang cukup mengkonsumsi makanan sumber kalsium. Nilai $95 \%$ confidence interval berdasarkan hasil analisis berada dalam rentang 2,4412,35. Oleh karena nilai batas bawah dan nilai batas atas 95\% CI tidak mencakup nilai 1 maka konsumsi makanan sumber kalsium merupakan faktor risiko yang signifikan terhadap kejadian osteoporosis (Tabel 2).

Jumlah responden yang setiap hari mengkonsumsi kopi pada kelompok kasus sebesar $23 \%$ sedangkan pada kelompok kontrol sebesar 19,7\%. Berdasarkan hasil analisis risiko, nilai OR untuk konsumsi kopi adalah 1,21 yang menunjukkan bahwa responden yang mengkonsumsi kopi setiap hari akan memiliki risiko 1,21 kali untuk mengalami osteoporosis dibandingkan dengan responden yang tidak setiap hari mengkonsumsi kopi. Nilai 95\% confidence interval berdasarkan hasil analisis berada dalam rentang 0,51-2,89. Oleh karena nilai batas bawah dan nilai batas atas 95\% CI mencakup nilai 1 maka konsumsi kopi bukan merupakan faktor risiko yang signifikan terhadap kejadian osteoporosis (Tabel 2).

Jumlah responden yang setiap hari mengkonsumsi teh pada kelompok kasus sebesar 44,3\% sedangkan pada kelompok kontrol sebesar 39,3\%.Berdasarkan hasil analisis risiko, nilai OR untuk konsumsi kopi adalah 1,22 yang menunjukkan bahwa responden yang mengkonsumsi teh setiap hari akan memiliki risiko 1,22 kali untuk mengalami osteoporosis dibandingkan dengan responden yang tidak setiap hari mengkonsumsi teh. Nilai $95 \%$ confidence interval berdasarkan hasil analisis berada dalam rentang 0,59-2,51. Oleh karena nilai batas bawah dan nilai batas atas 95\% CI mencakup nilai 1 maka konsumsi teh bukan merupakan faktor risiko yang signifikan terhadap kejadian osteoporosis (Tabel 2).

Jumlah responden yang setiap hari mengkonsumsi soft drink pada kelompok kasus sebesar $31,1 \%$ sedangkan pada kelompok kontrol sebesar 13,1\%.Berdasarkan hasil analisis risiko, nilai OR untuk konsumsi soft drink adalah 2,997 yang menunjukkan bahwa responden yang mengkonsumsi soft drink setiap hari akan memiliki risiko 2,997 kali untuk mengalami osteoporosis dibandingkan dengan responden yang tidak setiap hari mengkonsumsi soft drink. Nilai 95\% confidence interval berdasarkan hasil analisis berada dalam rentang 1,19-7,52. Oleh karena nilai batas bawah dan nilai batas atas 95\% CI tidak mencakup nilai 1 maka konsumsi soft drink merupakan 
faktor risiko yang signifikan terhadap

kejadian osteoporosis (Tabel 2).

Tabel 2. Kejadian Osteoporosis Berdasarkan Faktor Risiko Di RSUP Dr. Wahidin Sudirohusodo Tahun 2012-2015

\begin{tabular}{cccccccc}
\hline Faktor Risiko & \multicolumn{4}{c}{ KejadianOsteoporosis } & n & $\%$ & Uji Statistik \\
& Kasus & \% & \multicolumn{2}{c}{ Kontrol } & & & \\
& & & & & & & \\
\hline Jenis Kelamin & 39 & 64,0 & 33 & 54,0 & 72 & 59,0 & OR=1,50 \\
Risiko Tinggi & 22 & 36,0 & 28 & 46,0 & 50 & 41,0 & $\mathrm{CI}(0,72-3,10)$ \\
Risiko Rendah & & & & & & & $\mathrm{p}=0,269$
\end{tabular}

Riwayat Keluarga

$\begin{array}{lccccccc}\text { Ya } & 3 & 4,9 & 0 & 0 & 3 & 2,5 & \mathrm{OR}=2,052 \\ \text { Tidak } & 58 & 95,0 & 61 & 100 & 119 & 98,0 & \mathrm{CI}(1,70-2,46) \\ & & & & & & & \mathrm{p}=0,079\end{array}$

Riwayat Diabetes Mellitus

$\begin{array}{lllllllc}\text { Ya } & 19 & 31,1 & 12 & 19,7 & 31 & 25,4 & \text { OR }=1,84 \\ \text { Tidak } & 42 & 68,9 & 49 & 80,3 & 91 & 74,6 & \text { CI }(0,80-4,24) \\ & & & & & & & p=0,145\end{array}$

\section{Aktivitas Fisik}

Risiko Tinggi

Risiko Rendah

$$
\begin{aligned}
& 43 \\
& 18
\end{aligned}
$$$$
70,5
$$$$
16
$$

45

26,2
73,8

59

48,4

51,6

$$
\begin{gathered}
\mathrm{CI}(3,04-14,8) \\
\mathrm{p}=0,000
\end{gathered}
$$

Konsumsi Sumber Kalsium

Risiko Tinggi
Risiko Rendah

$49 \quad 80,3 \quad 26$

42,6
57,4

75

61,5

$\mathrm{OR}=5,497$

$12 \quad 19,7 \quad 35$

57,4

38,5

CI $(2,44-12,35)$

$\mathrm{p}=0,000$

Konsumsi Kopi

Ya
Tidak

$14 \quad 23,0$

12

$19,7 \quad 26$

21,3

$80,3 \quad 96 \quad 78,7$
$\mathrm{OR}=1,21$
CI $(0,51-2,89)$
$\mathrm{p}=0,658$

Konsumsi Teh

$\begin{array}{lccccccc}\text { Ya } & 27 & 44,3 & 24 & 39,3 & 51 & 41,8 & \text { OR }=1,224 \\ \text { Tidak } & 34 & 55,7 & 37 & 6,7 & 71 & 58,2 & \text { CI }(0,596-2,516) \\ & & & & & & & p=0,582\end{array}$

Konsumsi Soft Drink

$\begin{array}{lllllllc}\text { Ya } & 55 & 84,6 & 44 & 67,7 & 99 & 76,2 & \text { OR=2,997 } \\ \text { Tidak } & 10 & 15,4 & 21 & 32,3 & 31 & 23,8 & \mathrm{CI}(1,194-7,520) \\ & & & & & & & \mathrm{p}=0,016\end{array}$

Sumber: Data Primer, 2015 


\section{Analisis Multivariat}

Aktivitas fisik, konsumsi sumber kalsium, dan konsumsi soft drink merupakan prediktor terhadap kejadian osteoporosis karena nilai $\mathrm{p}$ yang dimiliki masing-masing variabel lebih kecil dari 0,05 . Berdasarkan nilai OR, variabel yang paling dominan berpengaruh terhadap kejadian osteoporosis adalah aktivitas fisik dengan nilai OR sebesar 4,739; 95\%CI:1,987-11,280), kemudian disusul konsumsi sumber kalsium $(\mathrm{OR}=3,180$; 95\%CI:1,293-7,819) dan konsumsi soft drink $(\mathrm{OR}=3,130 ; 95 \% \mathrm{CI}$ 1,080-9,069)

(Tabel 3).

Tabel 3. Hasil Uji Regresi Logistik Berganda

\begin{tabular}{lccccccc}
\hline \multicolumn{1}{c}{ Variabel } & \multirow{2}{*}{ B } & \multirow{2}{*}{ SE } & Wald & \multirow{2}{*}{ Nilai p } & \multirow{2}{*}{ OR } & \multicolumn{2}{c}{ 95\% CI } \\
& & & & & & Lower & Upper \\
\hline Aktivitas Fisik & 1,555 & 0,443 & 12,314 & 0,000 & 4,734 & 1,987 & 11,280 \\
Sumber Kalsium & 1,157 & 0,459 & 6,349 & 0,012 & 3,180 & 1,293 & 7,819 \\
Soft Drink & 1,141 & 0,543 & 4,420 & 0,036 & 3,130 & 1,080 & 9,069 \\
Constan & $-2,142$ & 0,570 & 14,104 & 0,000 & 0,117 & &
\end{tabular}

\section{Sumber: Data Primer, 2015.}

\section{PEMBAHASAN}

Dalam penelitian ini terlihat bahwa ada beberapa aspek yang secara signifikan mempengaruhi kejadian osteoporosis diantaranya aktivitas fisik, konsumsi makanan sumber kalsium, dan konsumsi soft drink.

Jenis kelamin merupakan salah satu faktor risiko terjadinya osteoporosis.Hasil analisis yang dilakukan menunjukkan bahwa jenis kelamin merupakan faktor risiko kejadian osteoporosis.Jenis kelamin perempuan memiliki risiko 1,50 kali lebih besar untuk mengalami osteoporosis dibandingkan dengan jenis kelamin lakilaki.Seseorang dengan jenis kelamin perempuan memiliki risiko yang lebih besar untuk mengalami osteoporosis, karena secara fisio-biologis perempuan akan mengalami menopause yang diiringi dengan menurunnya kadar estrogen. Penurunan kadar estrogen akan mengakibatkan peningkatan bone turn over dimana lebih banyak terjadi resorpsi tulang daripada pembentukan tulang, yang menyebabkan meningkatnya pengeroposan tulang.

Penelitian ini sejalan dengan dengan penelitian Wahyuni (2008) yang mengemukakan bahwa jenis kelamin tidak berhubungan secara signifikan untuk terjadinya osteoporosis, karena hasil analisis yang diperoleh bahwa proporsi kebiasaan merokok pada laki-laki 90,9\% lebih besar dibandingkan dengan perempuan $9,1 \%$. Menurut teori, merokok secara berlebihan akan mengurangi kekuatan tulang dan berpotensi menyebabkan osteoporosis (Fox-Spencer, 2007).

Faktor genetika juga memiliki kontribusi terhadap massa tulang.Hasil penelitian yang dilakukan menunjukkan bahwa riwayat keluarga merupakan faktor risiko terhadap kejadian osteoporosis.Seseorang yang memiliki riwayat keluarga osteoporosis memiliki risiko 2,05 kali lebih besar untuk mengalami osteoporosis dibandingkan dengan mereka yang tidak memiliki riwayat keluarga osteoporosis.Fatmah (2008), mengemukakan bahwa faktor genetik berkontribusi dalam terjadinya densitas mineral tulang, salah satu anggota keluarga yang memiliki densitas mineral tulng tidak normal, maka terjadinya osteoporosis pada keturunannya adalah $80 \%$.

Penelitian ini sejalan dengan penelitian yang dilakukan oleh Pambudi (2015), yang mengemukakan bahwa mereka yang mempunyai keluarga dengan riwayat osteoporosis memiliki risiko lebih besar untuk mengalami osteoporosis.Sama 
halnya dengan penelitian yang dilakukan oleh Pratiwi (2014), yang mengemukakan bahwa keluarga yang pernah mengalami osteoporosis memiliki hubungan yang signifikan untuk terjadinya osteoporosis.Hal ini dikaitkan dengan pola konsumsi produk-produk susu dan hasil olahan makanan sumber kalsium yang dikonsumsi.

Hasil penelitian yang dilakukan menunjukkan bahwa riwayat diabetes mellitus bukan merupakan faktor risiko terhadap kejadian osteoporosis. Seseorang yang memiliki riwayat diabetes mellitus akan berisiko 1,84 kali lebih besar untuk mengalami osteoporosis dibandingkan dengan mereka yang tidak memiliki riwayat diabetes mellitus.Dari hasil wawancara peneliti dan responden, hal yang ditemukan kebanyakan responden kurang menyadari untuk memeriksakan glukosa darah mereka di unit pelayanan kesehatan terdekat. Responden hanya akan mengetahui bahwa mereka menderita diabetes ketika keluarganya membawa mereka ke pelayanan kesehatan dengan kondisi penyakit yang lain.

Penelitian ini sejalan dengan penelitian yang dilakukan oleh Kridiana (2013), tidak ditemukan hubungan kejadian fraktur dengan penderita diabetes mellitus tipe I.ketidaksesuaian ini disebabkan adanya perbedaan antara pemeriksaan densitas tulang dengan tempat terjadinya fraktur. Pada diabetes mellitus tipe II, densitas tulang pada wanita tidak terjadi penurunan. Hal ini disebabkan pembentukan massa tulang yang lebih daripada normal, yang berhubungan dengan peningkatan indeks massa tubuh pada diabetes melitus tipe II.

Aktivitas fisik merupakan pilar penting manajemen osteoporosis untuk mencegah terjadinya penurunan densitas tulang yang dapat mengakibatkan terjadinya osteoporosis.Hasil penelitian yang dilakukan menunjukkan bahwa responden yang tidak teratur dalam melakukan aktivitas fisik akan memiliki risiko 6,719 kali lebih besar untuk mengalami osteoporosis dibandingkan dengan responden yang teratur dalam melakukan aktivitas fisik.Hal ini didukung oleh teori Berning et al., (2015) yang mengatakan olahraga baik untuk memperkuat tulang, dimana olahraga dapat memperlambat penurunan massa tulang akibat usia dan mengurangi risiko osteoporosis.

Hasil penelitian ini sejalan dengan penelitian yang dilakukan oleh Rotikan (2006), terjadi peningkatan densitas mineral tulang pada wanita usia reproduktif yang melakukan olaharaga dengan pembebanan secara teratur, seperti senam aerobik. Rahayu (2005)\& Permatasari (2008), dalam penelitiannya mengemukakan bahwa ada hubungan yang bermakna antara aktivitas olahraga dengan densitas mineral tulang, dimana proporsi subyek yang tidak berolahraga lebih besar daripada proporsi yang berolahraga.

Hampir seluruh kalsium di dalam tubuh ada dalam tulang yaitu $99 \%$ dan $1 \%$ berada dalam jaringan lunak.Hasil penelitian yang dilakukan menunjukkan bahwa responden yang kurang mengkonsumsi makanan sumber kalsium memiliki risiko 5,49 kali untuk mengalami osteoporosis dibandingakan dengan responden yang cukup dalam mengkonsumsi makanan sumber kalsium.Makanan sumber kalsium merupakan faktor risiko untuk terjadinya osteoporosis.Hasil ini didukung oleh penelitian Rahayu (2004), yang mengatakan adanya hubungan yang bermakna antara asupan kalsium dengan densitas mineral tulang.Berning et al., (2015) menemukan bahwa pembentukan tulang, absorpsi kalsium, dan resorpsi kalsium berhubungan secara linear pada wanita dewasa dan wanita dengan osteoporosis pascamenopause atau skoliosis.

Kopi mengandung senyawa non-gizi yang berpengaruh terhadap kesehatan tulang diantaranya yaitu kafein.Hasil penelitian yang dilakukan, menunjukkan bahwa konsumsi kopi bukan merupakan faktor risiko terhadap osteoporosis.Responden yang 
mengkonsumsi kopi setiap hari berisiko 1,21 kali untuk mengalami osteoporosis jika dibandingakan dengan reponden yang mengkonsumsi kopi tidak setiap hari.

Peneliti tidak dapat mengetahui seberapa besar pengaruh kafein terhadap kalsium karena peneliti tidak mengukur berapa porsi sumber kafein yang telah dikonsumsi responden.Hasil penelitian ini sejalan dengan hasil penelitian Lioyd (1997) yang dilakukan terhadap 138 orang perempuan menyebutkan tidak ada hubungan yang bermakna antara kafein dengan densitas mineral tulang (Nurrika, 2002).

Setiap tahun terjadi peningkatan penjualan minuman bersoda (soft drink) di dunia. Beberapa zat yang sering ditambahkan ke dalam soft drink antara lain kafein, saccharin, fruktosa, asam benzoat, asam sorbat, aspartam, dan asam fosfat. Minuman yang mengandung asam fosfat, fruktosa dan kafein dicurigai memberikan efek negatif terhadap tulang.Hasil penelitian yang menunjukkan bahwa konsumsi soft drink merupakan faktor risiko untuk terjadinya osteoporosis. Responden yang menkonsumsi soft drink memiliki risiko 2,997 kali lebih besar untuk mengalami osteoporosis dibanding dengan responden yang tidak mengkonsumsi soft drink.

Penelitian ini sejalan dengan penelitian L Tucker et al (2006) yang menunjukkan ada hubungan antara soft drink dan hipokalsemia, fraktur, atau Bone Mineral Density. Remaja perempuan yang mengkonsomsi soft drink memiliki resiko osteoporosis 3 kali lebih besar dibandingkan mereka yang tidak.Pada wanita post menopause didapati serum kalsium yang rendah $(\leq 8.8 \mathrm{mg} \mathrm{Ca} / \mathrm{dL}$ dibanding $>8.8 \mathrm{mg} \mathrm{Ca} / \mathrm{dL}$ ) karena secara signifikan mengkonsumsi $\geq 1$ cola per hari.Hal ini membuktikan bahwa kandungan kafein dan fosfat dalam cola dapat mempengaruh Bone Mineral Density.

Pemanis buatan yang biasa ditambahkan dalam soft drink adalah highfructose corn syrup (HFCS). Konsumsi fruktosa meningkatkan ekspresi 24hydroxylase (CYP24A1) dan menurunkan 1 $\alpha$-hydroxylase (CYP27B1), sehingga apabila kadarnya berlebih dalam waktu lama dapat mengurangi pembentukan 1,25$(\mathrm{OH}) 2 \mathrm{D} 3$ (bentuk aktif vitamin D) yang berfungsi sebagai transporter kalsium di intestinal. Penurunan transporter kalsium di intestinal dapat menyebabkan penurunan vitamin D yang beredar dalam tubuh, panjang tulang, berat tulang total, namun tidak mempengaruhi kadar PTH serum (Veronique et al., 2012).

Penelitian yang dilakukan menunjukkan bahwa konsumsi teh bukan merupakan faktor risiko untuk terjadinya osteoporosis.Teh mengandung kafein, tetapi juga mengandung zat gizi lain, seperti flavonoids, yang dapat mempengaruhi massa tulang dengan cara yang berbeda (Hegarty et al., 2000).Penelitian ini sejalan dengan penelitian Chenet al., (2013), hasil yang diperoleh bahwa tidak ada hubungan konsumsi teh dengan risiko fraktur.Hal ini membuktikan bahwa efek dari konsumsi teh pada struktur tulang tidak selalu berhubungan dengan risiko osteoporosis (Devine et al., 2007).

Aktivitas fisik, konsumsi sumber kalsium, dan konsumsi soft drink merupakan prediktor yang signifikan terhadap kejadian osteoporosis.Hal tersebut sejalan denganteori yang dikemukakan oleh Setyohadi \& Nuhonni (2012), bahwa pencegahan sedini mungkin untuk terjadinya osteoporosis yang intinya adalah berolahraga secara teratur, mengkonsumsi makanan dengan gizi seimbang dengan unsure kaya serat dan kaya kalsium, serta hindari mengkonsumsi soft drink.

\section{KESIMPULAN DAN SARAN}

Kesimpulan dalam penelitian ini adalah riwayat keluarga, aktivitas fisik, konsumsi sumber kalsium, dan konsumsi soft drink merupakan faktor risiko yang signifikan terhadap tingkat disabilitas. Sedangkan yang merupakan prediktor tingkat disabilitas adalah aktivitas fisik, 
konsumsi sumber kalsium, dan konsumsi soft drink. Disarankan bagi masyarakat untuk menjalani pola hidup sehat dengan teratur melakukan olahraga selama 30-45 menit, konsumsi makanan tinggi kalsium, dan membatasi minuman soft drink untuk memperkecil risiko terjadinya tingkat disabilitas yang berat.

\section{DAFTAR PUSTAKA}

Berning, J., Moe, G., Kelley, D., \& ByrdBredbenner, C. (2015). Wardlaw's Perspectives in Nutrition: McGrawHill Education.

Chen, H., Deng, L., \& Li, J. (2013).

Prevalence of Osteoporosis and Its Associated Factors among Older Men with Type 2 Diabetes. Int $\mathbf{J}$ Endocrinol, 2013. doi: $10.1155 / 2013 / 285729$

Depkes, R. I. (2008). Keputusan Menteri

Kesehatan Republik Indonesia Nomor

1142/MENKES/SK/XII/2008 tentang Pedoman Pengendalian Osteoporosis - [PERATURAN]. Jakarta: Departemen Kesehatan.

Devine, A., Hodgson, J. M., Dick, I. M., \& Prince, R. L. (2007). Tea drinking is associated with benefits on bone density in older women. The American journal of clinical nutrition, 86(4), 1243-1247.

Fatmah. (2008). Osteoporosis dan Faktor Risikonya pada Lansia Etnis Jawa. Media Medika Indonesiana, 43(2), 57-67.

Fox-Spencer, R. (2007). Simple Guide: Osteoporosis: Erlangga.

Hegarty, V. M., May, H. M., \& Khaw, K.T. (2000). Tea drinking and bone mineral density in older women. The American journal of clinical nutrition, 71(4), 1003-1007.

Hernlund, E., Svedbom, A., Ivergård, M., Compston, J., Cooper, C., Stenmark, J., . . . Kanis, J. (2013). Osteoporosis in the European Union: medical management, epidemiology and economic burden. Archives of osteoporosis, 8(1-2), 136.

IOF. (2010a). The Breaking Spine. Switzerland: International Osteoporosis Foundation (IOF).

IOF. (2010b). Osteoporosis Fact Sheet. Switzerland: International Osteoporosis Foundation (IOF).

Juniati, Suarnianti, \& Basri. (2012). Faktor-Faktor yang Berhubungan dengan Kejadian Osteoporosis yang Dirawat di RS Islam Faisal. l(5).

Kridiana, O. (2013). Faktor Risiko Osteoporosis Pada Wanita Pascamenopause (Studi di Rumah Sakit Umum Daerah Kota Semarang) Tahun 2012. Universitas Negeri Semarang.

L Tucker, Katherine. Morita, Kyoko. Qiao, Nning. T Hannan, Marian. Adrienne Cupples, L. P kiel, Douglas. (2006). Colas, but not other carbonated beverages, are associated with low bone, mineral density in older women: the framingham osteoporosis study. The American Journal

Nurrika, D. (2002). Hubungan Asupan Kalsium, Protein, dan Fosfor dengan Densitas Mineral Tulang Pada Perempuan Usia 45-55

Tahun. Fakultas Kesehatan Masyarakat, Universitas Indonesia, Jakarta.

Pambudi, J. (2015). Kebiasaan Buruk Yang Merusak Kesehatan Tulang

Permatasari, T. A. E. (2008). Hubungan Antara Indeks Massa Tubuh Dengan Kejadian Osteoporosis Pada Kelompok Usia 40-65 Tahun di Kota Depok. Universitas Indonesia, Jakarta.

Pratiwi, R. (2014). Faktor-Faktor Yang Berhubungan Dengan Kejadian Osteoporosis Di Puskesmas Pondok Betung. Universitas Islam Negeri Syarif Hidayatullah, Jakarta.

Rahayu, N. B. (2005). Faktor-Faktor Yang Berhubungan Dengan Tingkat 
Kepadatan Mineral Tulang Remaja Pada Siswa SMAN 3 Depok Fakultas Kesehatan Masyarakat, Universitas Indonesia.

Rotikan. (2006). Peranan Olahraga Dalam Mengatasi Masalah Osteoporosis. Jakarta: Persatuan Osteoporosis Indonesia.

RSUP, D., Wahidin Sudirohusodo. (2015). Laporan Rekam Medik: Jumlah Kasus Osteoporosis Tahun 20132015. Makassar: Rumah Sakit Umum Pendidikan Dr. Wahidin Sudirohusodo

Setyohadi, B., \& Nuhonni, S. A. (2012). Osteoporosis \& Penyakit Tulang Metabolik. Jakarta.

Syahrir, S. K., Agusyanti, S., Nurmiyati, Ernawati Parura, S. K., \& Gasang, S. S. (2015). Profil Kesehatan Sulawesi Selatan 2014. Makassar: Dinas Kesehatan Provinsi Sulawesi Selatan.

Tandra, H. (2009). Segala sesuatu yang harus anda ketahui tentang osteoporosis: mengenal, mengatasi, dan mencegah tulang keropos: PT Gramedia Pustaka Utama.

Trihapsari, E. (2009). Faktor-faktor yang Berhubungan dengan Densitas Mineral Tulang Wanita $\geq 45$ Tahun di Departemen Pendidikan Nasional, Jakarta. Fakultas Kesehatan Masyarakat. Universitas Indonesia.

Veronique D, Yves S, Jacklyn L, Chirag P, Francis W. K, John D.B, et al. (2012). Excessive fructose intake causes 1,25-(OH)2D3-dependent inhibition of intestinal and renal calcium transport in growing rats. American journal of physiologyendocrine and metabolism

Wahyuni, D. (2008). Faktor-Faktor yang Berhubungan dengan Osteopenia Pada Kelompok Vegetarian Umur 20-35 Tahun di Pusdiklat Maitreyawira. Universitas Indonesia, Jakarta. 